\title{
Study of Different Printing Design Type Polymer Samples Prepared by Additive Manufacturing
}

\author{
Lucie Zarybnicka ${ }^{1,2^{*}}$, Karel Dvorak1 ${ }^{1}$ Zdenka Dostalova1', Hana Vojackova \\ ${ }^{1}$ Department of Technical Studies, College of Polytechnics Jihlava, Tolsteho 1556/16, Jihlava, 586 01, Czech Republic \\ ${ }^{2}$ Institute of Theoretical and Applied Mechanics of the Czech Academy of Sciences, Centre Telc, \\ Prosecka 809/76, Praha 9, 190 00, Czech Republic \\ * Corresponding author, e-mail: Zarybnicka.L@email.cz
}

Received: 08 March 2019, Accepted: 12 July 2019, Published online: 10 October 2019

\begin{abstract}
3D printing is one of the most progressive additive technologies today. It finds its application also in industry. In terms of mechanical properties, the printing design of the product is an important parameter. The presented study investigates the effects of the printing design of a thin-walled 3D polymer model on the mechanical properties of the model. The material used for printing was acrylonitrilebutadiene-styrene (ABS) and the 3D print method was Fused Deposition Modeling (FDM). ABS was tested at various die temperatures and with various printing designs at a constant 3D print speed and identical print bed temperature. We examined the effect of printing temperature and product printing design on the resulting mechanical properties. We compared theoretical and experimental results by CAE-FEM Advanced Simulation modules. Results tensile deformations at maximum load by experiment and simulations are comparable. The best results of testing the mechanical properties were found in the pattern printed at a $45^{\circ}$ angle at temperature $285^{\circ} \mathrm{C}$.
\end{abstract}

Keywords

thin-walled model, ABS, FDM, mechanical properties, simulation

\section{Introduction}

Fused Deposition Modeling (FDM) is one of the most popular 3D printing methods. It is an additive manufacturing technology that was patented in 1989 by S. Scott Crump [1-2]. The term additive manufacturing refers to the process by which the product is formed by gradual deposition of thin layers on top of one another [3-5]. The FDM method makes it possible to create products from different types of materials ranging from metals to biological materials [6-12].

The most widely used polymers that are used for this technique include ABS (the acrylonitrile-butadiene-styrene terpolymer) and PLA (polylactic acid) [13-15]. As their use in both commercial and non-commercial sectors is ever expanding, it is important to ensure obtaining required mechanical and thermal properties by proper selection of 3D print temperatures as well as the print bed temperatures, which also have a great impact on the resulting product. Finally, choosing the correct print speed is crucial. The influence of surface and structure of $3 \mathrm{D}$ models on their mechanical properties was studied by numerous scientific groups [16-21].
$\mathrm{ABS}$ is one of the most widely used polymers for FDM printing. The ABS material itself has been tested by several groups [22, 23]. It consists of $15-35 \%$ acrylonitrile, $5-30 \%$ butadiene and $40-60 \%$ styrene. ABS is generally rigid, tough, low-absorbent, and non-toxic, individual types being resistant to low and high temperatures. This material is non-biodegradable. It is, however, recyclable. It is used for electronic housings and automotive bumper parts.

The 3D printed parts have lower strength when compared to parts made by a conventional process like injection molding. The strength of FDM parts can be increased by parameters optimization or by polymer materials reinforcement $[24,25]$. Their mechanical properties depend on the printing parameters [26, 27]. The best tensile properties are obtained when filaments are oriented longitudinally and parallel to the loading direction, and the worst tensile properties are obtained when samples are loaded along the build direction due to weak interlayer bonding $[28,29]$. For ABS samples, the largest ultimate strength was observed for $0^{\circ}$ raster angle compared to $45^{\circ}$ and 
$90^{\circ}$ raster angles [30]. The honeycomb is a very common test structure of 3D models [31]. Build orientation has a larger impact on the elastic deformation than print orientation [32]. The mechanical properties of the ABS material were verified by comparing FDM and injection molding. The results show that the choice of FDM parameters makes it possible to achieve comparable mechanical properties with conventional methods of processing (mold injection) [33]. An interesting application for FDM is also testing of various additives into polymeric materials. Multiwall carbon nanotubes (MWCNTs) as additives for ABS were tested for electrical and mechanical properties [34]. Tensile test results of specimens built in different orientations showed that ABS reinforced with $5 \%$ by weight $\mathrm{TiO} 2$ exhibited the highest ultimate tensile strength for specimens built in both horizontal and vertical directions with 32.2 and $18.4 \mathrm{MPa}$, respectively [35].

A suitable tool for subsequent simulation of test conditions for prepared samples is Computer Aided Engineering-Finite Element Method (CAE-FEM), where simulations of both mechanical and thermal properties can be performed [36-38]. CAE-FEM is a field of application in medicine and industry [39-44], which has numerous advantages. It saves time and money, improves designs, reduces errors in the design and drawing process, the impacts of parameters change on a system can be studied with more accuracy, and visualization is easy [45]. Experimental and simulation results indicate that the mechanical behavior of additive manufactured lattice structures depends on not only the lattice orientation but also the printing direction [46]. In order to promote the mechanical analysis and design of 3D printing structures, the ultimate tensile strength of FDM PLA with different printing angles was studied [47, 48].

This work focused on testing printing design of a 3D polymer model with respect to mechanical properties. Three types of structure printing design were tested at different temperatures of $3 \mathrm{D}$ printing while maintaining identical speed and temperature of the print bed. $45^{\circ}$ and $90^{\circ}$ raster angles were selected and the test structure used was honeycomb. The samples were characterized using thermal analysis by means of differential scanning calorimeter (DSC), thermal analysis (TGA), mechanical testing and using digital optical microscope. It was done for each type of tensile test according to experimental results using CAE-FEM Advanced Simulation modules. The simulations showed how much the temperature of production affects the mechanical properties. Results tensile deformations at maximum load by experiment and simulations are comparable at print temperature $285^{\circ} \mathrm{C}$.

\section{Experimental part \\ 2.1 Materials}

The ABS filaments were obtained from the supplier ESUN, Shenzhen, China. The filament has a diameter of $3.0 \mathrm{~mm}$ (accuracy 2.9-3.0 mm).

\subsection{Methods}

3D printing was performed using a Prusa i3 Plus 3D printer with a $0.4 \mathrm{~mm}$ nozzle, layer height from $0.05 \mathrm{~mm}$, maximum speed $200 \mathrm{~mm} / \mathrm{s}$, step size in $\mathrm{X} / \mathrm{Y}$ axis $-0.01 \mathrm{~mm}$, and the working area of $8000 \mathrm{~cm}^{3}\left(200 \times 200 \times 200 \mathrm{~mm}^{3}\right)$, with an integrated LCD.

Generally, models are created and edited by both parametric and nonparametric methods. More complex models are created by the method of free surface shaping. For basic analyses, CAD diagnostics tools are used, and CAE-FEM Advanced Simulation modules serve for advanced analysis. In our study, the export of models was done in *.stl format (STereoLithography). A Siemens NX CAx CAD module was used for new model creating, model editing, model analysis and measurement, and export to the post-processing format.

As for post-processing, the creation of ISO-G codes with the *.stl format model was performed in Slic3R (Prusa i3 Plus), and the nozzle-extruder path was generated at defined levels with the defined material, temperatures and print speeds. The postprocessor contains information on consumed material and print time. ISO G code can be created and edited manually; it is a syntax text file.

To test the mechanical properties, an Instron 3345 with a load of $5 \mathrm{kN}$ was used. The tensile test was done at the speed of $5 \mathrm{~mm} / \mathrm{min}$ and with the load of $5 \mathrm{kN}$. The bending test was performed with the following parameters: speed $200 \mathrm{~N} / \mathrm{min}$, jaw gap $6 \mathrm{~cm}$, and load $5 \mathrm{kN}$.

Thermal properties of the used ABS material were verified with DSC $200 \mathrm{~F} 3$ Maia within the temperature range from $-170{ }^{\circ} \mathrm{C}$ to $500{ }^{\circ} \mathrm{C}$. Measurements were performed in a nitrogen atmosphere at the heating rate of $10{ }^{\circ} \mathrm{C} / \mathrm{min}$. The sample weight ranged from 1 to $5 \mathrm{mg}$.

Thermal Analysis (STA 504) is a method based on the measurement of changes in mass thermogravimetry (TG) and heat flow Differential thermal analysis (DTA) simultaneously, as function of temperature. Measurements were performed in a nitrogen atmosphere at a heating rate of $20{ }^{\circ} \mathrm{C} / \mathrm{min}$, in the temperature range $25-500{ }^{\circ} \mathrm{C}$. The sample weight ranged from 5 to $10 \mathrm{mg}$. 
Viscoelastic properties (melt flow index) of the used ABS were characterized by extrusion plastometer Ceast with the following parameters: preheating w/o load $240 \mathrm{~s}$, test condition: temperature $220{ }^{\circ} \mathrm{C}$, load $10 \mathrm{~kg}$, measuring length $10 \mathrm{~mm}$, step length $0.25 \mathrm{~mm}$, measure starting time $300 \mathrm{~s}$, density of material $1.04 \mathrm{~g} / \mathrm{cm}^{3}$; die: diameter-length $2.095 \times 8.00 \mathrm{~mm}$.

Images were taken using a Keyence VHX-6000 optical microscope with VHX-S600E Free-angle observation system ( $Z$ motorized). Samples were also characterized in terms of surface quality.

\subsection{Characterization of material}

The ABS material was tested by DSC because it is very important to know thermal parameters for the selected $3 \mathrm{D}$ print temperature and the print bed temperature. The glass transition temperature $(\mathrm{Tg})$ and heat capacity $(\Delta \mathrm{Cp})$ were determined by DSC. The glass transition temperature is expressed as the temperature at which the Gibbs free energy is such that the activation energy allows the cooperative movement of molecular chain segments to slide past each other when a force is applied. When the glass temperature has been reached, the stiffness stays the same until the temperature exceeds $\mathrm{Tg}$, and the material turns rubbery [49].

ABS material was tested by thermal analysis. It is very important for the process to know a good temperature of $3 \mathrm{D}$ print and temperature of the plate [50].

Determining the melt flow index (MFI) is the second important characteristic for the correct 3D printing process. This parameter was determined by a MFI measuring device and it is defined as the measure of the ease of melt flow of thermoplastic material in gram over the course of $10 \mathrm{~min}$ at a certain standard temperature [51]. Melt flow rate is an indirect measure of molecular weight, with high melt flow rate corresponding to low molecular weight. At the same time, melt flow rate is a measure of the ability of the material's melt to flow under pressure. Melt flow rate is inversely proportional to viscosity of the melt [52].

Another significant characteristic is the mechanical properties of the used material. Samples were characterized by tensile testing in form filaments and 3D printed samples. These properties were determined by Instron 3345 with a load of $5 \mathrm{kN}$.

The manufacturer declares the following properties of the supplied material: density $1.04 \mathrm{~g} / \mathrm{cm}^{3}$, melt flow index $12.0 \mathrm{~g} / 10 \mathrm{~min}$, tensile strength $43.0 \mathrm{MPa}$, elongation at break $22.0 \%$ and bending strength $66.0 \mathrm{MPa}$.

\subsection{Preparation of samples}

Samples were created using a 3D printer by the FDM method. A dogbone was selected as the test product and it was tested by ASTM D-638, ISO 527 (Fig. 1). Three type filling of samples (Fig. 2) were prepared for the tensile test. Print temperatures were selected between 245$285{ }^{\circ} \mathrm{C}$ and $80{ }^{\circ} \mathrm{C}$ for the bed, the print speed was the same for all the samples. The samples were printed at the angles of $45^{\circ}$ and $90^{\circ}$ and as honeycomb. The speed of $3 \mathrm{D}$ print was $70 \mathrm{~mm} / \mathrm{s}$ and the diameter of the nozzle was $0.4 \mathrm{~mm}$. The thickness of the layer was $0.25 \mathrm{~mm}$ [13]. The first three layers and the last three layers were always printed as rectilinear type for each model.

\subsection{Simulation}

The results obtained by testing the prepared samples were used to set simulations at the maximum load and a half load of the samples. The simulation was performed according to the experimental testing using CAE-FEM Advanced Simulation modules. Simulations were performed by the
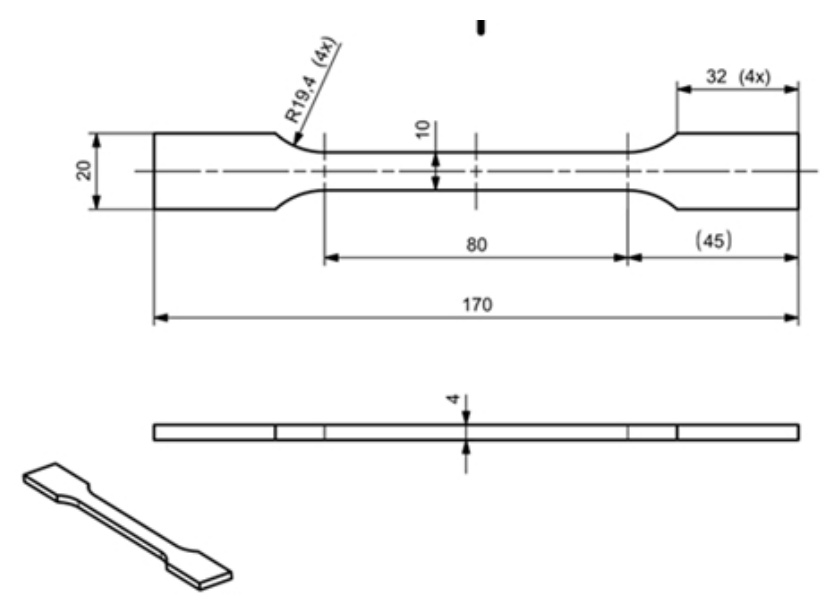

Fig. 1 Diamensions of sample for tensile test.

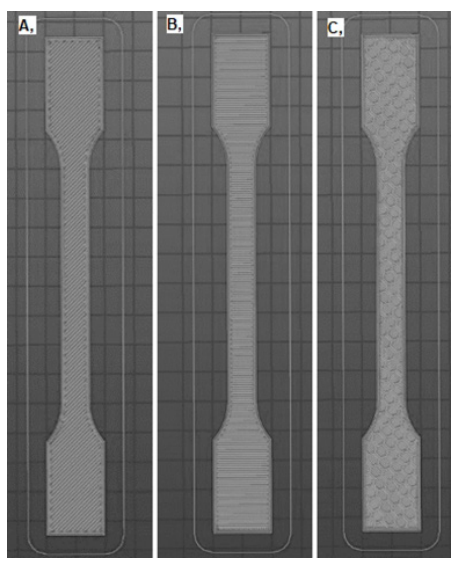

Fig. 2 The printing design of the dogbone sample - A - $45^{\circ}$ printing orientation, $\mathrm{B}-90^{\circ}$ printing orientation, $\mathrm{C}-3 \mathrm{D}$ print as honeycomb. 
forces that were actually developed on samples during tensile testing. The simulation is based on the application of experimentally obtained maximum loads for each sample type. Other simulations are based on the maximum load applied during the experiments.

An identical 3D model of the test specimen is used for the simulation test. The assigned material corresponds to the modified used material (ABS). The modification relates to the modulus of elasticity detected by the test on real samples. An identical, non-idealized model is used to create the finite element method FEM network. The FEM network (Fig. 3) is the same for the entire body, the body has not been partitioned because it is a relatively simple model and the distribution of the network does not affect the accuracy or the calculation time. The mesh is a 3D mesh composed of four walls. The size of the element (min. 2 elements) is chosen to be $2 \mathrm{~mm}$. The greater network density is not relevant and will not contribute to increased calculation accuracy; on the contrary, singularities may occur in curved parts, i.e. irrelevant local evaluation.

Simulation boundary conditions are as follows:

- Fixed attachment of one end of the bar, corresponding to the attachment to the lower stationary jaw of the tearing machine.

- Stressing by a defined force tangent to the surfaces of the other end of the rod, corresponding to the attachment and stress by the upper movable jaw of the tearing device.

- The magnitude of the force is chosen to achieve the appropriate stress at the yield point determined.

\section{Results and discussion}

\subsection{Characterization of the test material}

The ABS terpolymer was determined by MFI measurement. The avg. mass-flow rate was $17.8 \mathrm{~g} / 10$ min with the standard deviation of $0.31 \mathrm{~g} / 10 \mathrm{~min}$. The avg. volume-flow rate was $17.1 \mathrm{~cm}^{3} / 10$ min with the standard of deviation $0.29 \mathrm{~cm}^{3} / 10 \mathrm{~min}$. We determined rheological data such as shear rate, shear stress and viscosity. The shear rate was $31.56 \mathrm{~s}-1$, the shear stress $89631 \mathrm{~Pa}$ and the viscosity 2839.82 Pa.s. These parameters are important for choosing the diameter of the nozzle and the speed of the $3 \mathrm{D}$ printing itself [53].

The tensile test of the ABS material was performed with the following results: maximum load $224.17 \mathrm{~N}$, tensile stress at maximum load $31.71 \mathrm{MPa}$, modulus of elasticity $1227.79 \mathrm{MPa}$ and tensile deformation at maximum load $4.79 \%$. The test was run on the ABS

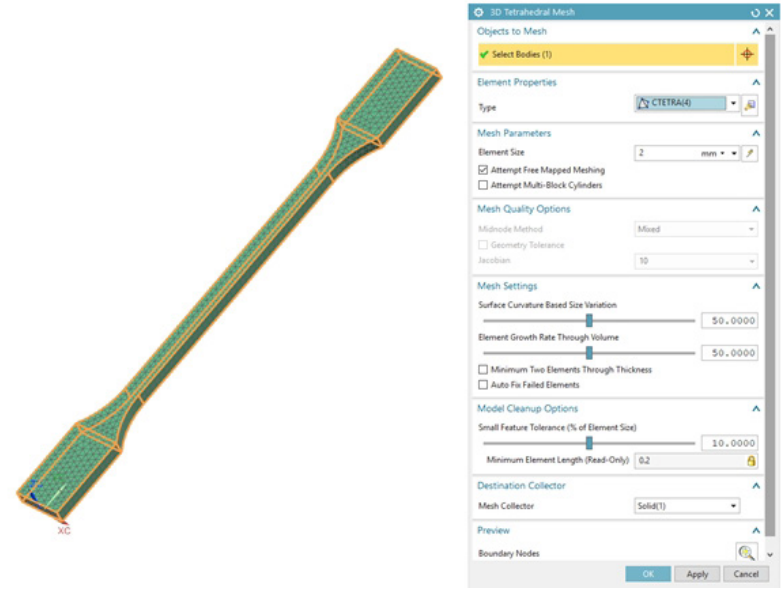

Fig. 3 FEM network for 3D model.

filament used and was repeated 10 times. The results did not match the assumptions based on the material sheet from the material supplier.

Thermal properties for this material were determined by DSC. The temperature of glass transition was determined at the value of $114.2{ }^{\circ} \mathrm{C}$ and $\Delta \mathrm{Cp}$ was $0.36 \mathrm{~J} /(\mathrm{g} . \mathrm{K})$. Thanks to these obtained parameters we can then monitor the effect of possible degradation under selected 3D printing conditions.

The 3D printing temperatures from $245{ }^{\circ} \mathrm{C}$ to $285^{\circ} \mathrm{C}$ were selected for testing the ABS material. These temperatures were chosen based on TG analysis (Table 1 and Fig. 4). The material supplier recommends a print temperature between $220-260{ }^{\circ} \mathrm{C}$. We chose the temperature range of $245-285^{\circ} \mathrm{C}$ for printing since when printing below $245^{\circ} \mathrm{C}$, the material did not flow continuously from the nozzle. There would be a need for more pressure on it, which could result in poor print quality.

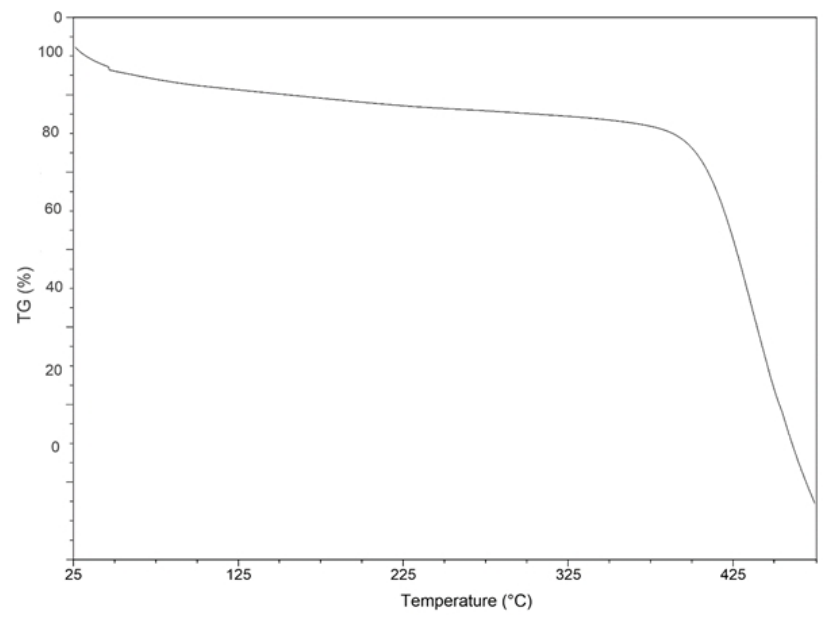

Fig. 4 TGA of ABS filament. 
Table 1 Thermal stability results.

\begin{tabular}{lcccccc}
\hline \multicolumn{6}{c}{ Weight loss (wt.\%) at temperature $\left({ }^{\circ} \mathrm{C}\right)$} \\
\hline Sample & 80 & 245 & 255 & 265 & 275 & 285 \\
ABS & 16.50 & 23.40 & 23.70 & 23.90 & 24.10 & 24.50 \\
\hline
\end{tabular}

\subsection{Characterization of the prepared samples}

The following $3 \mathrm{D}$ print parameters were selected based on testing the ABS material. The samples were prepared at five temperatures of $245,255,265,275$, and $285^{\circ} \mathrm{C}$, at the constant print bed temperature of $80^{\circ} \mathrm{C}$ and the constant speed of printing of $70 \mathrm{~mm} / \mathrm{s}$. The prepared samples were tested by tensile test and by DSC. The results of testing the prepared samples by tensile testing can be seen in Tables 4-6. Results of tensile test for the $45^{\circ}$ dogbone were as follows (Table 2). The lowest values for maximum load, tensile stress at maximum load, and Young's flexural modulus are shown in a sample with a print temperature of $245^{\circ} \mathrm{C}$. The highest values are shown in a sample with a print temperature of $285^{\circ} \mathrm{C}$. The only result that was better for a sample with a print temperature of $245^{\circ} \mathrm{C}$ is the result of tensile deformation at maximum load with $3.3 \%$ versus $2.9 \%$ for samples with a print temperature of $285^{\circ} \mathrm{C}$. This result corresponds to the theory, since at a higher temperature there is a slight crosslinking of the double bonds which are in the ABS $f$ and thus the toughness increases. This effect dominates the very printing design of the $3 \mathrm{D}$ product.

Results of the tensile test for $90^{\circ}$ dogbone were as follows (Table 3). The lowest values for maximum load, tensile stress at maximum load, and Young's modulus are shown in a sample with a print temperature of $245^{\circ} \mathrm{C}$. The highest values are shown in a sample with a print temperature of $285^{\circ} \mathrm{C}$. Unlike the dogbone sample at $45^{\circ}$, which is the most compact of all prepared printing designs, the results for tensile deformation at maximum load were better at $285^{\circ} \mathrm{C}$ print temperature with value $3.9 \%$ against $1.8 \%$ at $245{ }^{\circ} \mathrm{C}$. The mechanical properties of the specimen are assumed to have a $90^{\circ}$ dogbone specimen with lower mechanical properties than $45^{\circ}$ dogbone specimens [54].

Results of tensile test for the honeycomb dogbone were as follows (Table 4). The lowest values for maximum load, tensile stress at maximum load, and Young's modulus are shown in a sample with a print temperature of $245^{\circ} \mathrm{C}$ too. The highest values are shown in a sample with a print temperature of $285^{\circ} \mathrm{C}$. Unlike the dogbone sample at $45^{\circ}$, which is the most compact of all prepared printing designs, the results for tensile deformation at maximum load were better at $285{ }^{\circ} \mathrm{C}$ print temperature with value $2.8 \%$ against $1.7 \%$ at $245{ }^{\circ} \mathrm{C}$.
Table 2 Results of tensile test for $45^{\circ}$ dogbone.

\begin{tabular}{ccccc}
\hline $\begin{array}{c}\text { Temperature } \\
\text { of 3D print } \\
\left({ }^{\circ} \mathrm{C}\right)\end{array}$ & $\begin{array}{c}\text { Max. } \\
\text { load } \\
(\mathrm{N})\end{array}$ & $\begin{array}{c}\text { Tensile stress } \\
\text { at max. load } \\
(\mathrm{MPa})\end{array}$ & $\begin{array}{c}\text { Young's } \\
\text { modulus } \\
(\mathrm{MPa})\end{array}$ & $\begin{array}{c}\text { Tensile } \\
\text { deformation at } \\
\text { max. load }(\%)\end{array}$ \\
\hline 245 & 829.1 & 19.8 & 997.5 & 3.3 \\
255 & 992.7 & 23.0 & 1111.7 & 3.2 \\
265 & 1131.6 & 26.6 & 1243.8 & 3.2 \\
275 & 1195.1 & 28.1 & 1301.1 & 3.0 \\
285 & 1225.9 & 28.4 & 1342.1 & 2.9 \\
\hline
\end{tabular}

Table 3 Results of tensile test for $90^{\circ}$ dogbone.

\begin{tabular}{ccccc}
\hline $\begin{array}{c}\text { Temperature } \\
\text { of 3D print } \\
\left({ }^{\circ} \mathrm{C}\right)\end{array}$ & $\begin{array}{c}\text { Max. } \\
\text { load } \\
(\mathrm{N})\end{array}$ & $\begin{array}{c}\text { Tensile stress } \\
\text { at max. load } \\
(\mathrm{MPa})\end{array}$ & $\begin{array}{c}\text { Young's } \\
\text { modulus } \\
(\mathrm{MPa})\end{array}$ & $\begin{array}{c}\text { Tensile } \\
\text { deformation at } \\
\text { max. load }(\%)\end{array}$ \\
\hline 245 & 380.6 & 9.1 & 676.8 & 1.8 \\
255 & 521.0 & 12.5 & 816.8 & 2.0 \\
265 & 686.9 & 16.3 & 1010.9 & 2.1 \\
275 & 816.9 & 20.1 & 1115.0 & 2.6 \\
285 & 951.1 & 23.2 & 1183.1 & 3.9 \\
\hline
\end{tabular}

Table 4 Results of tensile test for honeycomb dogbone.

\begin{tabular}{ccccc}
\hline $\begin{array}{c}\text { Temperature } \\
\text { of 3D print } \\
\left({ }^{\circ} \mathrm{C}\right)\end{array}$ & $\begin{array}{c}\text { Max. } \\
\text { load } \\
(\mathrm{N})\end{array}$ & $\begin{array}{c}\text { Tensile stress } \\
\text { at max. load } \\
(\mathrm{MPa})\end{array}$ & $\begin{array}{c}\text { Young's } \\
\text { modulus } \\
(\mathrm{MPa})\end{array}$ & $\begin{array}{c}\text { Tensile } \\
\text { deformation at } \\
\text { max. load }(\%)\end{array}$ \\
\hline 245 & 321.3 & 8.2 & 559.8 & 1.7 \\
255 & 334.4 & 8.5 & 582.7 & 1.8 \\
265 & 461.2 & 11.1 & 691.4 & 2.1 \\
275 & 493.4 & 11.9 & 703.6 & 2.5 \\
285 & 536.1 & 13.0 & 731.2 & 2.8 \\
\hline
\end{tabular}

In all cases the temperature $285^{\circ} \mathrm{C}$ was achieved by samples with the best result of mechanical testing - specifically tensile test. Test results at $285^{\circ} \mathrm{C}$ by individual 3D printing methods can be seen in Table 5. The best results of max. load, tensile stress at maximum and the Young's modulus were found for the dogbone with $3 \mathrm{D}$ print at $45^{\circ}$. The dogbone with $3 \mathrm{D}$ print at $90^{\circ}$ had the best result for tensile deformation at the maximum load of $3.9 \%$. The results are compared against the used ABS filament material (Table 5). Samples exhibit better adhesion of individual layers with increasing temperature, and therefore also better mechanical properties. The results correlate with the theory [55] that with increasing processing temperature the impact strength values increase. In our case, this theory is confirmed by the results of Yong's modulus of elasticity.

We have used DSC for measuring the temperature of glass transition of the products (Table 6). For each system, we have measured the following results of glass transition temperature, the corresponding thermal capacities of the 
Table 5 Summarized results of tensile test at $285{ }^{\circ} \mathrm{C}$ and material before $3 \mathrm{D}$ print.

\begin{tabular}{ccccc}
\hline $\begin{array}{c}\text { Method of } \\
\text { 3D print }\end{array}$ & $\begin{array}{c}\text { Max. } \\
\text { load } \\
(\mathrm{N})\end{array}$ & $\begin{array}{c}\text { Tensile stress } \\
\text { at max. load } \\
(\mathrm{MPa})\end{array}$ & $\begin{array}{c}\text { Young's } \\
\text { modulus } \\
(\mathrm{MPa})\end{array}$ & $\begin{array}{c}\text { Tensile } \\
\text { deformation at } \\
\text { max. load }(\%)\end{array}$ \\
\hline $\begin{array}{c}\text { ABS } \\
\text { filament }\end{array}$ & 224.2 & 31.7 & 1227.8 & 4.8 \\
$45^{\circ}$ & 1225.9 & 28.4 & 1342.1 & 2.9 \\
$90^{\circ}$ & 951.1 & 23.2 & 1183.1 & 3.9 \\
honeycomb & 536.1 & 13.0 & 731.2 & 2.8 \\
\hline
\end{tabular}

Table 6 Results of thermal testing.

\begin{tabular}{ccc}
\hline $\begin{array}{c}\text { Temperature of } \\
\text { 3D print }\left({ }^{\circ} \mathrm{C}\right)\end{array}$ & $\operatorname{Tg}\left({ }^{\circ} \mathrm{C}\right)$ & $\Delta \mathrm{Cp}(\mathrm{J} /(\mathrm{g} \cdot \mathrm{K}))$ \\
\hline only filament & 114.2 & 0.360 \\
245 & 114.0 & 0.355 \\
255 & 112.8 & 0.345 \\
265 & 112.8 & 0.344 \\
275 & 112.7 & 0.320 \\
285 & 111.4 & 0.310 \\
\hline
\end{tabular}

thermal process are always given in brackets. In the case of ABS, oxidation processes lead to a degradation of the material at higher temperatures in the presence of oxygen. Mainly the polybutadiene phase (which is in possession of reactive double bonds) is affected by oxidation reactions [56]. Branching of the PB may occur and the flexibility of the strands may decrease [57]. This is manifested by lowering the glass transition temperature and $\Delta \mathrm{Cp}$ of the product.

All 3D printed samples were also evaluated using a digital optical microscope. The analysis of the quality of the individual layers was carried out always from the side of the prepared sample. Fig. 5 shows the compactness analysis that features red grains, which make the layers less compact. This phenomenon is also related to the results of mechanical properties testing. At the printing temperature of $285^{\circ} \mathrm{C}$., no interplay between the individual layers is evident, so the sample is more cohesive, which is also due to better mechanical properties. We analyzed area without damages. For samples printed at $245^{\circ} \mathrm{C}$, the result was $73.68 \%$; at $255^{\circ} \mathrm{C}$, the result was $98.41 \%$. Samples printed at $265-285{ }^{\circ} \mathrm{C}$ had values between $99.98-99.99 \%$. As the study states, a trial and error process is needed to produce quality parts, for example, using a $45^{\circ}$ angle. Smaller angled surfaces are susceptible to defects, but no theoretical basis is fully defined, so a numerical model is needed. The model can predict problem areas in printing, reduce experimental prints, and provide more usable parts [58].
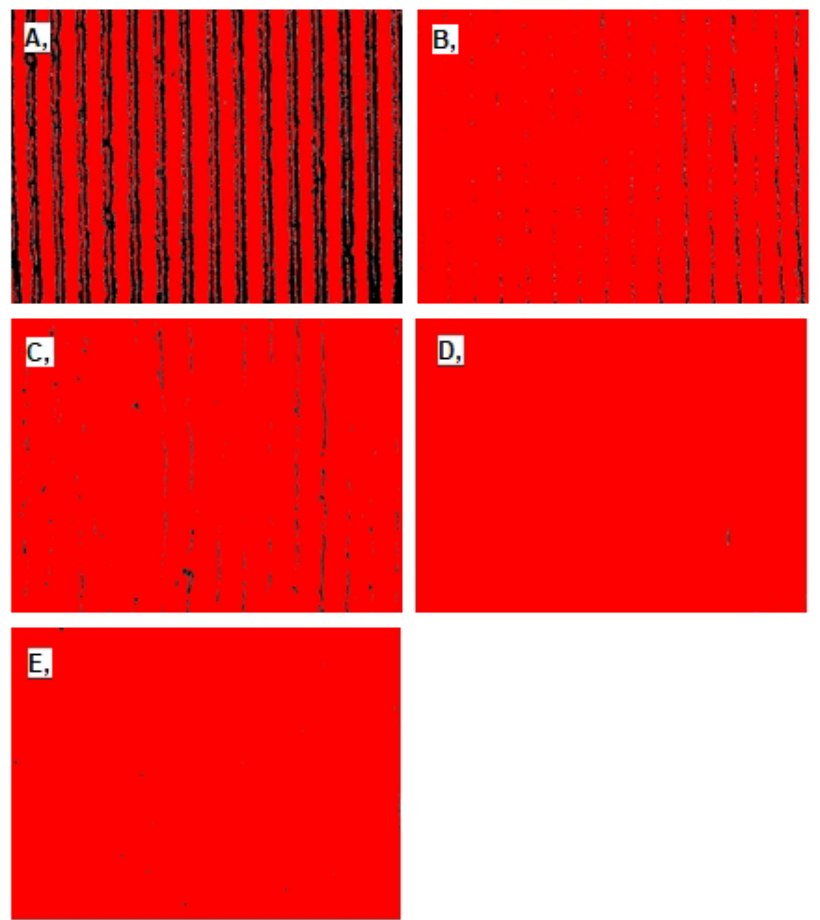

Fig. 5 Compactness analysis for all samples - A - print at $245^{\circ} \mathrm{C}$, $\mathrm{B}$ - print at $255^{\circ} \mathrm{C}, \mathrm{C}$ - print at $265^{\circ} \mathrm{C}, \mathrm{D}$ - print at $275^{\circ} \mathrm{C}$, $\mathrm{E}-$ print at $285^{\circ} \mathrm{C}$

\subsection{Simulation of tensile test}

CAE-FEM Advanced Simulation modules were used to compare the experimental results, simulating the same process as the picking device on the individual sample types. The load and attachment have been simulated so as to bring the attachment in the blasting device as close as possible. Samples were always loaded with the maximum load (1225.9 $\mathrm{N}$ for a dogbone with print at $45^{\circ}, 951.1 \mathrm{~N}$ for a dogbone with print at $90^{\circ}$, and $536.1 \mathrm{~N}$ for a dogbone with honeycomb structure) and with a half load (612.95 N for a dogbone with print at $45^{\circ}, 475.55 \mathrm{~N}$ for a dogbone with print at $90^{\circ}$, and $268.05 \mathrm{~N}$ for a dogbone with honeycomb structure). You can see all samples of the simulation with maximum load in Fig. 6. The printing design of the test product was taken into account as opposed to the processing temperature for simulations.

The simulation was performed at the highest achievable force of $1225.9 \mathrm{~N}$ in a dogbone with print at $45^{\circ}$ to monitor the effect of the defined force on the deformation and stress of the specimen that was applied to the dogbone with print at $90^{\circ}$ of the dogbone with honeycomb structure. These simulations have the following results. The sample dogbone with print at $90^{\circ}$ showed at maximum force values of 


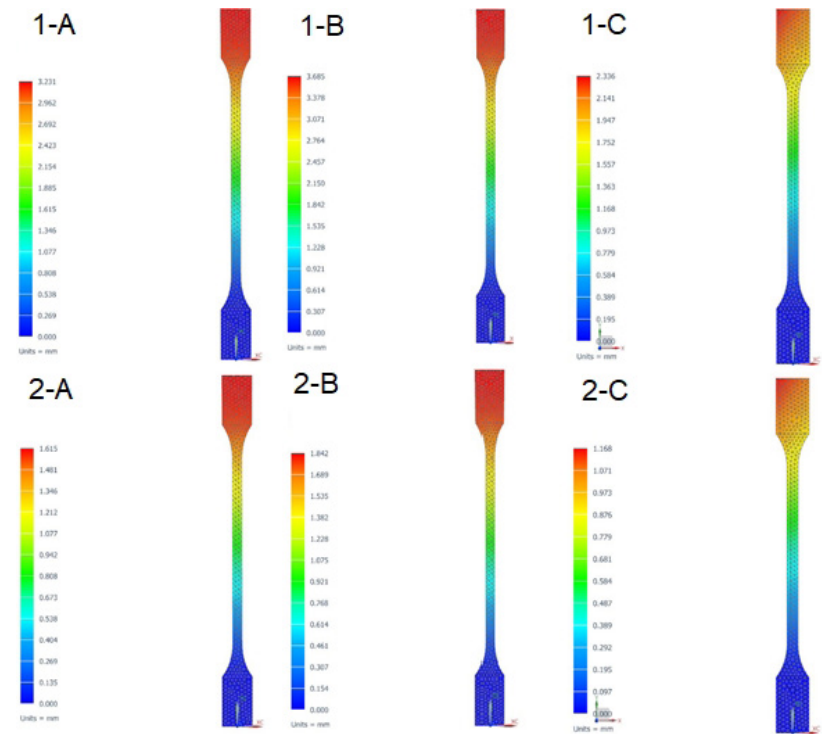

Fig. 6 Simulation with max. load for all samples - 1-A - max. load for $45^{\circ}$ sample, $2-\mathrm{A}$ - half load for $45^{\circ}$ sample, 1-B - max. load for $90^{\circ}$ sample, 2-B - half load for $90^{\circ}$ sample, 1-C - max. load for honeycomb sample, 2-C - half load for honeycomb sample

tensile deformation $3.7 \%$. The sample dogbone with the honeycomb structure showed at maximum force values of tensile deformation $2.3 \%$.

The simulation was done without thermal loading, so the results are not affected by the thermal effect of the printing design of the $3 \mathrm{D}$ product only. The summary results can be seen in Table 7 and we can see how much the temperature affects the mechanical properties of the ABS product. In general, the theoretical results for tensile deformation at maximum load are little higher in case the dogbone with print at $90^{\circ}$ and honeycomb and lower in case the dogbone with print at $45^{\circ}$. From the results it can be seen that the correct temperature is influenced by the maximum load and stress values. When testing deformation at maximum load, the differences between experimental measurements and simulations are not so numerous.

\section{References}

[1] Stratasys "Legal Information. 3D Printing and Additive Manufacturing" [online]. Available at: http://www.stratasys.com/ legal/legal-information [Accessed: 12 September 2018]

[2] United States Patent and Trademark Office "Using the Trademark Electronic Search System" [online]. Available at: https://www. uspto.gov/trademarks-application-process/searching-trademarks/using-trademark-electronic-search-system [Accessed: 12 September 2018]
Table 7 Comparison of the results of tensile test at maximum load for samples - experimental vs. simulation.

\begin{tabular}{cccc}
\hline $\begin{array}{c}\text { Method of } \\
\text { 3D print }\end{array}$ & $\begin{array}{c}\text { Max. load } \\
(\mathrm{N})\end{array}$ & $\begin{array}{c}\text { Tensile Deformation at Maximum Load (\%) } \\
\text { Experimental at } \\
285^{\circ} \mathrm{C} \text { print }\end{array}$ & $\begin{array}{c}\text { Simulation without } \\
\text { thermal loading }\end{array}$ \\
\hline $45^{\circ}$ & 1225.9 & 2.9 & 3.2 \\
$90^{\circ}$ & 951.1 & 3.9 & 3.7 \\
honeycomb & 536.1 & 2.8 & 2.3 \\
\hline
\end{tabular}

\section{Conclusion}

Sample sets were prepared at five printing temperatures from $245{ }^{\circ} \mathrm{C}$ to $285^{\circ} \mathrm{C}$ with a different product structure - a dogbone with a honeycomb 3D print structure, a structure $3 \mathrm{D}$ printed at $90^{\circ}$ angle, and one $3 \mathrm{D}$ printed at $45^{\circ}$. First, the product degradation with respect to $3 \mathrm{D}$ print temperature was verified by the DSC method. As the 3D print temperatures rise from 245 to $285^{\circ} \mathrm{C}$, there is a slight $13 \%$ structure change of the ABS structure due to thermal loading and pressure on the material. We selected $70 \mathrm{~mm} / \mathrm{s}$ as the $3 \mathrm{D}$ printing speed; this has no significant influence on the degradation of the product quality. The thickness of the layer was $0.25 \mathrm{~mm}$. The quality of the product would be greatly influenced by wrong temperature of the bed, but as the ABS material has the glass transition temperature above $110{ }^{\circ} \mathrm{C}$, the temperature of $80^{\circ} \mathrm{C}$ was selected [59]. The best tensile test results were shown by the samples printed at $285{ }^{\circ} \mathrm{C}$ and the sample of a dogbone with 3D print at $45^{\circ}$ with tensile stress at maximum load $28.4 \mathrm{MPa}$ and maximum load by the force of $1225.9 \mathrm{~N}$. The best result of the tensile deformation of $3.9 \%$ was achieved by the sample with $3 \mathrm{D}$ print at $90^{\circ}$. The simulations showed how much the temperature of production affects the mechanical properties of the product. The results of tensile deformation at maximum load were comparable.

\section{Acknowledgment}

This research was supported by the College of Polytechnics, Jihlava, under Grant no. 1170/004/1816 "Preparation and testing of new materials using a miniextruder".

[3] Sood, A. K., Ohdar, R. K., Mahapatra, S. S. "Experimental investigation and empirical modelling of FDM process for compressive strength improvement", Journal of Advanced Research, 3(1), pp. 81-90, 2012.

https://doi.org/10.1016/j.jare.2011.05.001

[4] Chua, C. K., Leong, K. F., Lim, C. S. "Rapid Prototyping: Principles and Applications in Manufacturing", World Scientific Publishing Co. Inc., River Edge, NJ, USA, 2003. 
[5] Gibson, I., Rosen, D. W., Stucker, B. "Additive Manufacturing Technologies: Rapid Prototyping to Direct Digital Manufacturing", Springer, Boston, MA, USA, 2010. https://doi.org/10.1007/978-1-4419-1120-9

[6] Ma, H., Feng, C., Chang, J., Wu, C. "3D-printed bioceramic scaffolds: from bone tissue engineering to tumor therapy", Acta Biomaterialia, 79, pp. 37-59, 2018.

https://doi.org/10.1016/j.actbio.2018.08.026

[7] Dudek, P. "FDM 3D printing technology in manufacturing composite elements", Archives of Metallurgy and Materials, 58(4), pp. 1415-1418, 2013.

https://doi.org//10.2478/amm-2013-0186

[8] Kelly, C. N., Miller, A. T., Hollister, S. J., Guldberg, R. E., Gall, K. "Design and Structure-Function Characterization of 3D Printed Synthetic Porous Biomaterials for Tissue Engineering", Advanced Healthcare Materials, 7(7), Article Number: 1701095, 2018 https://doi.org/10.1002/adhm.201701095

[9] Sharma, R., Singh, R., Penna, R., Fraternali, F. "Investigations for mechanical properties of Hap, PVC and PP based 3D porous structures obtained through biocompatible FDM filaments", Composites Part B: Engineering, 132, pp. 237-243, 2018. https://doi.org/10.1016/j.compositesb.2017.08.021

[10] Ranganathan, S. I., Kim, T. W. B., Campbell, D. J., Smith, G. C. "Novel Biodegradable and Non-biodegradable 3D Printed Implants", United States, 15/736,885 (Filed), 2018.

[11] Dixit, C. K., Kadimisetty, K., Rusling, J. "3D-printed miniaturized fluidic tools in chemistry and biology", TrAC Trends in Analytical Chemistry, 106, pp. 37-52, 2018. https://doi.org/10.1016/j.trac.2018.06.013

[12] Liu, C. G., Zeng, Y. T., Kankala, R. K., Zhang, S. S., Chen, A. Z., Wang, S. B. "Characterization and Preliminary Biological Evaluation of 3D-Printed Porous Scaffolds for Engineering Bone Tissues", Materials, 11(10), Article Number: 1832, 2018. https://doi.org/10.3390/ma11101832

[13] Nuñez, P. J., Rivas, A., García-Plaza, E., Beamud, E., SanzLobera, A. "Dimensional and Surface Texture Characterization in Fused Deposition Modelling (FDM) with ABS plus", Procedia Engineering, 132, pp. 856-863, 2015 https://doi.org/10.1016/j.proeng.2015.12.570

[14] Torrado, A. R., Shemelya, C. M., English, J. D., Lin, Y., Wicker, R. B., Roberson, D. A. "Characterizing the effect of additives to ABS on the mechanical property anisotropy of specimens fabricated by material extrusion 3D printing", Additive Manufacturing, 6, pp. 16-29, 2015 . https://doi.org/10.1016/j.addma.2015.02.001

[15] Zeltmann, S. E., Gupta, N., Tsoutsos, N. G., Maniatakos, M., Rajendran, J., Karri, R. "Manufacturing and Security Challenges in 3D Printing", The Journal of The Minerals, Metals \& Materials Society (TMS), 68(7), pp. 1872-1881, 2016. https://doi.org/10.1007/s11837-016-1937-7

[16] Takagishi, K., Umezu, S. "Development of the Improving Process for the 3D Printed Structure", Scientific Reports, 7, Article Number: 39852, 2017. https://doi.org/10.1038/srep39852
[17] Torrado, A. R., Roberson, D. A. "Failure Analysis and Anisotropy Evaluation of 3D-printed Tensile Test Specimens of Different Geometries and Print Raster Patterns", Journal of Failure Analysis and Prevention, 16(1), pp. 154-164, 2016. https://doi.org/10.1007/s11668-016-0067-4

[18] Hutmacher, D. W. "Scaffolds in tissue engineering bone and cartilage", Biomaterials, 21(24), pp. 2529-2543, 2000. https://doi.org/10.1016/S0142-9612(00)00121-6

[19] Monkova, K., Monka, P. "Qualitative parameters of complex part produced by additive approach", In: 2017 8th International Conference on Mechanical and Aerospace Engineering (ICMAE), Prague, Czech Republic, 2017, pp. 691-694. https://doi.org/10.1109/ICMAE.2017.8038732

[20] Paul, R., Anand, S. "Optimization of layered manufacturing process for reducing form errors with minimal support structures", Journal of Manufacturing Systems, 36, pp. 231-243, 2015. https://doi.org/10.1016/j.jmsy.2014.06.014

[21] Capkova, V. "Technologické aspekty stavby kovových součástí metodou rapid prototyping" (Restrictive parameters of 3D printing), MSc Thesis, University of West Bohemia, 2015. (in Czech)

[22] Melnikova, R., Ehrmann, A., Finsterbusch, K. "3D printing of textile-based structures by Fused Deposition Modelling (FDM) with different polymer materials", IOP Conference Series: Materials Science and Engineering, 62, Article Number: 012018, 2014. https://doi.org/10.1088/1757-899X/62/1/012018

[23] Weng, Z., Wang, J., Senthil, T., Wu, L. "Mechanical and thermal properties of $\mathrm{ABS} /$ montmorillonite nanocomposites for fused deposition modeling 3D printing", Materials \& Design, 102, pp. 276-283, 2016. https://doi.org/10.1016/j.matdes.2016.04.045

[24] Ngo, T. D., Kashani, A., Imbalzano, G., Nguyen, K. T. Q., Hui, D. "Additive manufacturing (3D printing): A review of materials, methods, applications and challenges", Composites Part B: Engineering, 143, pp. 172-196, 2018. https://doi.org/10.1016/j.compositesb.2018.02.012

[25] Mohamed, O. A., Masood, S. H., Bhowmik, J. L. "Optimization of fused deposition modelling process parameters: a review of current research and future prospects", Advances in Manufacturing, 3(1), pp. 42-53, 2015 https://doi.org/10.1007/s40436-014-0097-7

[26] Ziemian, C., Sharma, M., Ziemian, S. "Anisotropic mechanical properties of ABS parts fabricated by fused deposition modelling", In: Mechanical Engineering, InTech, Rijekta, Croatia, 2012, pp. $159-180$

[27] Durgun, I., Ertan, R. "Experimental investigation of FDM process for improvement of mechanical properties and production cost", Rapid Prototyping Journal, 20(3), pp. 228-235, 2014. https://doi.org/10.1108/RPJ-10-2012-0091

[28] Ahn, S. H., Montero, M., Odell, D., Roundy, S., Wright, P. K. "Anisotropic material properties of fused deposition modelling ABS", Rapid Prototyping Journal, 8(4), pp. 248-257, 2002. https://doi.org/10.1108/13552540210441166 
[29] Letcher, T., Waytashek, M. "Material Property Testing of 3D-Printed Specimen in PLA on an Entry-Level 3D Printer", In: Proceedings of the ASME 2014 International Mechanical Engineering Congress \& Exposition, Montreal, Quebec, Canada, 2014, Article number: V02AT02A014. https://doi.org/10.1115/IMECE2014-39379

[30] Ziemian, C. W., Ziemian, R. D., Haile, K. V. "Characterization of stiffness degradation caused by fatigue damage of additive manufactured parts", Materials \& Design, 109, pp. 209-218, 2016. https://doi.org/10.1016/j.matdes.2016.07.080

[31] Zhang, P., Arceneaux, D. J., Khattab, A. "Mechanical properties of 3D printed polycaprolactone honeycomb structure", Journal of Applied Polymer Science, 135(12), Article Number: 46018, 2018. https://doi.org/10.1002/app.46018

[32] Panda, B., Leite, M., Biswal, B. B., Niu, X., Garg, A. "Experimental and numerical modelling of mechanical properties of $3 \mathrm{D}$ printed honeycomb structures", Measurement, 116, pp. 495-506, 2018. https://doi.org/10.1016/j.measurement.2017.11.037

[33] Dawoud, M., Taha, I., Ebeid, S. J. "Mechanical behaviour of ABS: An experimental study using FDM and injection moulding techniques", Journal of Manufacturing Processes, 21, pp. 39-45, 2016. https://doi.org/10.1016/j.jmapro.2015.11.002

[34] Sezer, H.K., Eren, O. "FDM 3D printing of MWCNT re-inforced ABS nano-composite parts with enhanced mechanical and electrical properties", Journal of Manufacturing Processes, 37, pp. 339-347, 2019.

https://doi.org/10.1016/j.jmapro.2018.12.004

[35] Torrado Perez, A. R., Roberson, D. A., Wicker, R. B. "Erratum to: Fracture Surface Analysis of 3D-Printed Tensile Specimens of Novel ABS-Based Materials", Journal of Failure Analysis and Prevention, 14(4), pp. 549-549, 2014.

https://doi.org/10.1007/s11668-014-9844-0

[36] Dvorak, K. "3D model preparing for rapid prototyping by FDM method", In: 2017 8th International Conference on Mechanical and Aerospace Engineering (ICMAE), Prague, Czech Republic, 2017, pp. 25-29. https://doi.org/10.1109/ICMAE.2017.8038611

[37] Staneva, N. "Trieskové a beztrieskové obrábanie dreva" (3D Modeling of shafts for woodworking machines), presented at Chip and Chipless Woodworking Processes 2014, Zvolen, Slovakia, 2014, pp. 151-156. (in Slovakian)

[38] Staneva, N., Genchev, Y., Hristodorova, D. "FEM analysis of deformations and stresses of upholstered furniture skeleton made of scots pine and OSB", International Journal - Wood, Design \& Technology, 6(1), pp. 31-37, 2017.

[39] Hudák, R., Kat'uch, P., Živčak, J. "Application of biomedical metrotomography", In: 2011 15th IEEE International Conference on Intelligent Engineering Systems, Poprad, Slovakia, 2011, pp. 411-415.

https://doi.org/10.1109/INES.2011.5954782

[40] Vartziotis, D., Vartziotis, K., Faessler, V., Savvas, E., Goudas, I., Zavali, M. "An online system for the support of Total Hip Arthroplasty and rapid implant design and manufacturing", In: Proceedings of the 10th IEEE International Conference on Information Technology and Applications in Biomedicine, Corfu, Greece, 2010, pp. 1-4.

https://doi.org/10.1109/ITAB.2010.5687706
[41] Cader, M. "The Estimation Method of Strength for TechnologyOriented 3D Printing Parts of Mobile Robots", In: International Conference Automation, Warsaw, Poland, 2017, pp. 367-379. https://doi.org/10.1007/978-3-319-54042-9_34

[42] Hürlimann, F., Kelm, R., Dugas, M., Oltmann, K., Kress, G. "Mass estimation of transport aircraft wingbox structures with a CAD/ CAE-based multidisciplinary process", Aerospace Science and Technology, 15(4), pp. 323-333, 2011.

https://doi.org/10.1016/j.ast.2010.08.005

[43] Puff, R., Bortoli, M. D. del, Bosco, R., Gaertner, E. L. "The Use of CAD/CAE Tools in Compressor Development Focusing Structural Analysis", In: International Compressor Engineering Conference at Purdue, Purdue, IN, USA, 2006, pp. 1-10.

[44] Meunier, M. "Industrial Applications of Molecular Simulations", CRC Press, Boca Raton, FL, USA, 2012.

https://doi.org/10.1201/b11485

[45] Pranoto, S. H., Mahardika, M. "Design and finite element analysis of micro punch CNC machine modeling for medical devices", AIP Conference Proceedings, 1941, Article Number: 020021, 2018. https://doi.org/10.1063/1.5028079

[46] Zhang, P., To, A. C. "Transversely isotropic hyperelastic-viscoplastic model for glassy polymers with application to additive manufactured photopolymers", International Journal of Plasticity, 80, pp. 56-74, 2016. https://doi.org/10.1016/j.ijplas.2015.12.012

[47] Yao, T., Deng, Z., Zhang, K., Li, S. "A method to predict the ultimate tensile strength of $3 \mathrm{D}$ printing polylactic acid (PLA) materials with different printing orientations", Composites Part B: Engineering. 163, pp. 393-402, 2019. https://doi.org/10.1016/j.compositesb.2019.01.025

[48] Chacón, J. M., Caminero, M. A., García-Plaza, E., Núñez, P. J. "Additive manufacturing of PLA structures using fused deposition modelling: Effect of process parameters on mechanical properties and their optimal selection", Materials \& Design, 124, pp. 143-157, 2017. https://doi.org/10.1016/j.matdes.2017.03.065

[49] Rahman, M., Schott, N. R., Sadhu, L. K. "Glass Transition of ABS in 3D Printing", In: Excerpt from the Proceedings of the 2016 COMSOL Conference in Boston, Boston, MA, USA, 2016, pp. 1-5. [online] Available at: https://www.comsol.it/paper/download/361301/rahman_paper.pdf [Accessed: 11 July 2019]

[50] Zarybnicka, L., Dvorak, K. "Optimalization of parameters for 3D print for acrylonitrile-butadiene-styrene by fused deposition modelling", International Research Journal of Engineering and Technology, 4(8), pp. 1054-1058, 2017.

[51] Kumar, R., Singh, R., Ahuja, I. P. S., Amendola, A., Penna, R. "Friction welding for the manufacturing of PA6 and ABS structures reinforced with Fe particles", Composites Part B: Engineering, 132, pp. 244-257, 2018. https://doi.org/10.1016/j.compositesb.2017.08.018

[52] Shenoy, A. V., Saini, D. R. "Thermoplastic Melt Rheology and Processing", Marcel Dekker Inc., New York, USA, 1996.

[53] Mostafa, N., Syed, H. M., Sbarski, I., Andrew, G. "A study of melt flow analysis of an ABS-Iron composite in fused deposition modelling process", Tsinghua Science and Technology, 14(S1), pp. 29-37, 2009.

https://doi.org/10.1016/S1007-0214(09)70063-X 
[54] Jap, N. S. F., Pearce, G. M., Hellier, A. K., Russell, N., Parr, W. C., Walsh, W. R. "The effect of raster orientation on the static and fatigue properties of filament deposited ABS polymer", International Journal of Fatigue, 124, pp. 328-337, 2019. https://doi.org/10.1016/j.ijfatigue.2019.02.042

[55] Maries, G. R. E., Chira, D. "Influence of Processing Temperatures of Acrylonitrile Butadiene Styrene (ABS), Polyamide 6.6 (PA 6.6) and Polyoxymethylene (POM) on Some Mechanical Properties when Injecting Items Used in the Automotive Industry Based on Mechanical Resistance Tests", Materiale Plastice, 49(4), pp. 288292, 2012

[56] Blom, H., Yeh, R., Wojnarowski, R., Ling, M. "Detection of degradation of ABS materials via DSC", Journal of Thermal Analysis and Calorimetry, 83(1), pp. 113-115, 2006.
[57] Bhowmick, A. K., Stephens, H. "Handbook of Elastomers", CRC Press, Boca Raton, FL, USA, 2000.

[58] Lischke, F., Tovar, A. "Design of Self-Supported 3D Printed Parts for Fused Deposition Modeling", In: ASME 2016 International Design Engineering Technical Conferences and Computers and Information in Engineering Conference, Charlotte, NC, USA, 2016, Article number: V004T05A009. https://doi.org/10.1115/DETC2016-60569

[59] Choi, Y. H., Kim, C. M., Jeong, H. S., Youn, J. H. "Influence of Bed Temperature on Heat Shrinkage Shape Error in FDM Additive Manufacturing of the ABS-Engineering Plastic", World Journal of Engineering and Technology, 4(3), pp. 186-192, 2016. https://doi.org/10.4236/wjet.2016.43D022 